\title{
Arkeolojik Kalıntılar Üzerine İnşa Edilen Müzelerin Tasarım Yaklaşımları
}

\author{
DOI: $10.26466 /$ opus.686817
}

\author{
* \\ Hicran Hanım Halaç* - Cemre Su Abac1 ${ }^{* *}$ - Hilal Dağl1 $1^{* * *}$ \\ * Doç. Dr., Eskişehir Teknik Üniversitesi, Mimarlık ve Tasarım Fakültesi, Eskişehir/ Türkiye \\ E-Posta: hhhalac@eskisehir.edu.tr ORCID: 0000-0001-8046-9914 \\ ** Doktora Öğr, Eskişehir Teknik Üniversitesi, Lisansüstü Eğitim Enstitüsü, Eskişehir/ Türkiye \\ E-Posta: cemresuabaci@gmail.com ORCID: 0000-0002-4511-3186 \\ *** Y.L , Eskişehir Teknik Üniversitesi, Lisansüstü Eğitim Enstitüsü, Eskişehir/ Türkiye \\ E-Posta: hilaldagli3@gmail.com ORCID: $\quad$ 0000-0001-6145-7803
}

\section{Öz}

Çalışmanın amacı, arkeolojik kalıntılar üzerine inşa edilen müzelerin tasarım yaklaşımlarını mevcut örnekler üzerinden ortaya koyarak bir tipoloji oluşturmaktır. Bunun yanı sıra araştırma, gelecekte tasarlanacak olan yeni yapılar için ön analiz niteliği taşımayı amaçlamaktadır. Bu amaç doğrultusunda belirlenen anahtar kelimeler açık erişimli web sitelerinde taranmış ve 24 adet yapıya ulaşılmıştır. Yapılar ölçüt örnekleme yöntemiyle çözümlenmiş ve 10 adet yapı araştırma kapsamının dışında kalmıştır. Geriye kalan 14 adet yapı içerik analizi yöntemiyle yeniden incelenmiş ve bu yapıların tasarım yaklaşımları analiz edilerek bir tipoloji elde edilmiştir. Yapıları tanıtmak amactyla öncelikle künye bilgileri verilerek sergi malzemeleri incelenmiştir. Sadece alandaki buluntularm sergilendiği müzeler $(\% 21,4)$ olduğu gibi başka arkeolojik alandan çıkarlan buluntuların sergilendiği müzelerin de $(\% 35,7)$ olduğu gözlemlenmiştir. Incelenen yapılarda buluntusu hakkında bilgiye erişilemeyen $(\% 42,8)$ yapılar da olmuştur. Oluşturulan tipolojide; yapılar, zemine oturan $(\% 78,5)$ ve zeminden yükseltilmiş $(\% 21,5)$ olarak ikiye ayrilmaktadır. Her iki kategorideki yapılar strüktürel sistemleri, cephe malzemeleri, çatı biçimleniş şekli, çatı strüktürü ve çatı malzemeleri yönünden incelenmiş ve kullanım sıklkları yüzdelik oranlarla ifade edilmiştir. Bununla birlikte zemine oturan ve zeminden yükseltilmiş yapılarda tercih edilen tasarım yaklaşımları karşılaştırılarak benzerlikler ve farklılar ortaya konmuştur.

Anahtar Kelimeler: Arkeolojik alanların korunması, yerinde koruma, koruma örtüleri, arkeoloji müzesi, koruyucu yapılar 


\title{
Design Approaches Of Museums Built On Archaeological Remains
}

\begin{abstract}
The study aims to create a typology by revealing museums design approaches built on archaeological ruins through existing examples. The research also aims to be a preliminary analysis of new structures to be designed in the future. The keywords determined for this purpose were scanned on open-access websites, and 24 structures were obtained as a result of the scanning. The structures were analyzed with the criterion sampling method, and ten buildings were excluded from the scope of the research. The remaining 14 buildings were re-examined using the content analysis method, and a typology was obtained by analyzing the design approaches of these structures. Firstly, the exhibition materials of buildings were examined and were given information about their identities in order to introduce them. It has been observed that there are museums where only findings from the site are exhibited (21,4\%), as well as museums where finds from other archaeological sites are exhibited $(35,7 \%)$. There were also structures in which information about the findings could not be reached in the examined structures $(42,8 \%)$. The created typology is divided into two as sitting on the ground $(78,5 \%)$ and raised from the ground (21,5\%). The buildings in both categories were examined in terms of structural systems, facade materials, roof form, roof structure, and roof materials, and their usage frequencies were expressed in percentages. Also, similarities and differences were revealed by comparing the design approaches preferred in the structures sitting on the ground and raised from the ground.
\end{abstract}

Keywords: Conservation of archeological sites, in situ conservation, covering structures, archaeological museum, protective structures 


\section{Giriş}

İnsanlar köklerinin nereden geldiğini, sosyal ve kültürel açıdan nasıl gelişim gösterdiklerini sürekli merak etmişler, bu meraklarını geçmiş ile bağlantı kurmaya çalışarak, tarihi yerleri ziyaret ederek, araştırma yaparak gidermeye çalışmışlardır. Arkeolojik alanlar; geçmişte yaşamış insanların yaşam alanlarını, yapım tekniklerini, kültürlerini, inanç sistemlerini, ritüellerini geçmişle bağlantı kurarak anlamamıza olanak sağlayan mekanlardır. Geçmişe ayna tutan bu alanları ve yapıları geleceğe aktarmak hem insanlık hem de mimarlık tarihi açısından önemlidir.

Koruma kavramı ilkçağlardan günümüze kadar çeşitli biçimlerde değişerek gelmiştir. Geçmişten gelen ya da mevcut zaman diliminde bulunan eserlerin, anıtların kulanım ömürlerini uzatarak geleceğe aktarma isteği bu kavramın oluşmasını sağlamıştır. Eski dönemlerde günümüz koşullarındaki gibi olmasa da onarma, taşıma, yapının malzemelerini başka bir alanda kullanma gibi koruma eylemleri yapılmaktaydı (Kaderli, 2014). Günümüzdeki koruma anlayışının ise Rönesans ile başladığı söylenebilir. Önceleri daha çok yapıları koruma anlayışı hakimken daha sonra bu kavram gelişerek daha büyük ölçekte koruma anlayışı kabul görmüş ve tarihi bir yapının sadece kendisinin değil çevresiyle beraber korunması düşüncesi kabul edilmiştir.

Uluslararası alanda koruma kriterleri 1931 yılında Atina Tüzügü̈nde, 1964 yılında Venedik Tüzüğ̈̈'nde ve 1975 yılında Amsterdam Bildirgesi'nde belirlenmiştir. Arkeolojik alanlarda koruma, Venedik Tüzüğü (ICOMOS, 1964) 'nün kazılar ile ilgili olan 15. maddesinin içeriğinde "Yikıntılar korunmal, mimari unsurlarn ve buluntularn sürekli olarak korunması için gerekli önlemler alınmahıdır. Bundan başka, kültür varlı̆̆ııı anlaşılmasımı kolaylaştıracak ve anlamın hiç bozmadan açı̆̆a çıkartacak her çareye başvurulmalıdır." olarak belirtilmiştir. ICOMOS Arkeolojik Mirasın Korunması ve Yönetimi Tüzüğü (ICOMOS, 1990) içeriğinde "arkeolojik miras" tanımı yapılmıştır. Bütünleşik koruma politikaları, yasa ve ekonomi, belgeleme, araştırma, bakım ve koruma, sunuş, bilgi, yeniden yapım, mesleki nitelikler, uluslararası işbirliği gibi başlıklar altında arkeolojik mirasın korunması ve yönetiminin nasıl yapılması gerektiği belirtilmiştir. Arkeolojik Mirasın Korunmasına İlişkin Avrupa Sözleşmesi'nde (Gözden Geçirilmiş) (Council of Europe, 1992); arkeolojik mirasın tanımı yapılmış, mirasın kimliğinin saptanması ve koruma 
önlemleri, arkeolojik araştırma ve korumanın finansmanı, bilimsel bilginin toplanması ve yayımı, kamuoyunun bilinçlendirilmesi, arkeolojik miras öğelerinin yasadışı dolaşımını önleme, karşılıklı teknik ve bilimsel yardımlaşma ve sözleşmenin (gözden geçirilmiş) uygulamasının, denetiminin nasıl yapılacağı açıklanmıştır.

Arkeolojik alanlarda ortaya çıkan kalıntıların ve buluntuların, eğer özel bir şekilde korunması gerekmiyorsa bulundukları ortamda korunmaları en doğru yöntemdir. Arkeolojik eserlerin mevcut ortamında çevresi ile birlikte bulunması hem eserlerin bir bütün olarak algılanmasını hem de eserlerin birbirleriyle olan ilişkilerinin kavranabilmesini sağlamaktadır. Literatürde In-situ olarak da geçen yerinde korunan alanları gezen ziyaretçiler, bu alanın kullanıldığı dönemde var olan insanların yaşayış biçimlerini, kullandıkları malzemeleri, aletleri, kalıntıların işlevlerini, o dönemde kullanılan yapım türlerini vb. genel bir bütün olarak görmekte, bunları göz önünde bulundurarak tarihi daha iyi anlayıp değerlendirebilmektedirler.

Venedik Tüzüğ̈̈ (ICOMOS, 1964)'nün; 7. maddesinde " Bir anıtın tanıklı ettiği tarihin ve içinde bulunduğu ortamın ayrlmaz bir parçasıdır. Kültür varlı̆̆ının tümünün, ya da bir parçasının başka bir yere taşınmasına - anıtın korunması bunu gerektirdiği, ya da çok önemli ulusal veya uluslararası çıkarlarm bulunduğu durumlar dışında - izin verilmemelidir." ve 8. maddesinde yer alan "Anıtın tamamlayıcı öğeleri sayılan heykel, resim gibi süslemeler, ancak bunlarn korumanın başka çaresi yoksa yerlerinden kaldırlabilir." hükümleri arkeolojik alanlarda ortaya çıkan kalıntıların ve buluntuların nasıl ve ne şekilde korunmaları gerektiğini düzenlemiştir. ICOMOS Arkeolojik Mirasın Korunması ve Yönetimi Tüzüğü (ICOMOS, 1990) 'nün 6. maddesinde, arkeolojik alanların yerinde korunmasına ilişkin olarak "Arkeolojik miras yönetiminin genel hedefi, bütün ilgili belge ve koleksiyonlarn da uzun vadeli koruma ve bakımın sağlayarak, ant ve sitleri yerinde korumak olmalıdır. Bu mirasın bazı öğelerinin yeni konumlara taşınması mirası özgün ortamında koruma kuralının çiŏnenmesi anlamına gelir. Bu ilke sürekli bakım, koruma ve yönetime olan gereksinimi vurgulamakta, ayrıca eğer kazıdan sonra gerekli bakım ve yönetim să̆lanamayacaksa, arkeolojik mirasın kazılarak ortaya çıkarılmamasım ve çıkarıldıktan sonra her türlü etkene açı bırakılmaması gerekliliğini hatırlatmaktadır." hükümleri yer almaktadır. Arkeolojik Mirasın Korunmasına İlişkin Avrupa Sözleşmesinin (Gözden Geçirilmiş) (Council of Europe, 1992) 4. maddesinde arkeolojik mirasın yerinde korunmasının ve bakımının yapılmasının uygun olduğu belirtilmiştir. 
Arkeolojik kalıntılar uzun süre toprak altında kalmışlardır ve bulundukları ortamda çoğu özelliklerini korumuşlardır. Arkeolojik kalıntılar kazı sonrası yüzeye çıarıldıklarında yeni ortama uyum sağlayamayabilirler. Bu nedenle kalıntıların dış etkenlere karşı korunmaları gereklidir. Bunun için çeşitli çözümler uygulanmaktadır (Dikilitaş, 2011). Genellikle kazı alanlarında kazı işlemi yapıldıktan sonra kalıntıların üzeri plastik örtüler veya geçici basit çatılar ile kapatılarak koruma sağlanmaya çalışılmaktadır. Ancak bu uygulama uzun süreli ve etkili bir çözüm olmamaktadır. Bu nedenle arkeolojik alanlarda kalıntıları daha etkili korumak ve aynı zamanda kalıntıların sergilenmesine yardımcı olmak amacıyla koruyucu yapılar/strüktürler inşa edilmektedir (Ahunbay, 2010).

Koruyucu yapılar ya da strüktürler; koruyucu çatılar, koruyucu kabuklar ve kalıntılar üzerine inşa edilmiş yapılar olarak ele alınabilir. Koruyucu çatılar kalıntıların sadece üzerini kaplayan yanları açık strüktürlerdir. Geçici çözüm sunmak ya da uzun süreli kullanım için tasarlanmış olabilirler. Bu durumda kullanılan malzeme ve strüktür belirleyici olmaktadır (Zeren ve Uyar, 2010). Koruyucu kabuklar, kalıntıların hem üstünü hem de yan yüzlerini kaplamaktadır. Bu sayede kalıntıların çevreden gelebilecek ve çevresel koşullardan oluşabilecek hasarlara karşı izole edilmesini sağlamaktadır. Çevresel faktörlerin değerlendirilmesiyle iç koşulların kontrolü sağlanarak kalıntıların korunması için uygun ortam oluşturulması amaçlanmaktadır (Aslan, 1997). Koruyucu çatılara Arslantepe Höyüğü'nün; koruyucu kabuklara da Çatalhöyük'ün üst örtüsü örnek verilebilir (Tablo 1).

Tablo1. Koruyucu çatı ve kabuk örneği

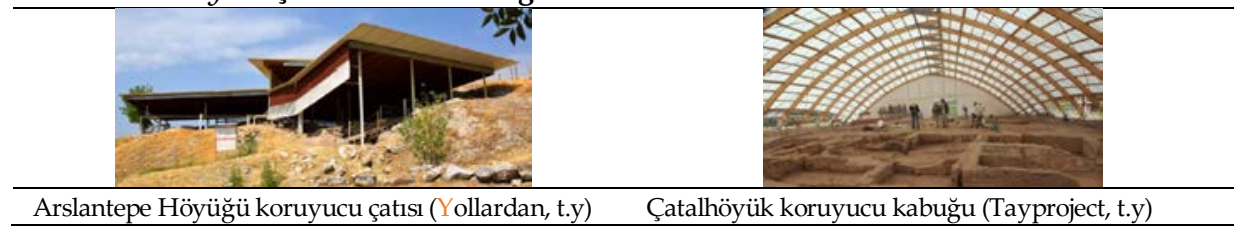

Kalıntılar üzerine inşa edilmiş olan yapılar ise, hem kalıntıların korumasını sağlamakta hem de alanın yeni bir işlev kazanmasını sağlamaktadır. Yeni inşa edilen bu yapılar otel, konut, müze gibi çeşitli işlevlere sahip olabilmektedir. Bu yapılara Antakya Müze Otel ve Manavgat'ta bulunan konut+ticaret karma kullanıma sahip bir yapı örnek verilebilir (Tablo 2). 
Tablo 2. Koruyucu yapı örnekleri

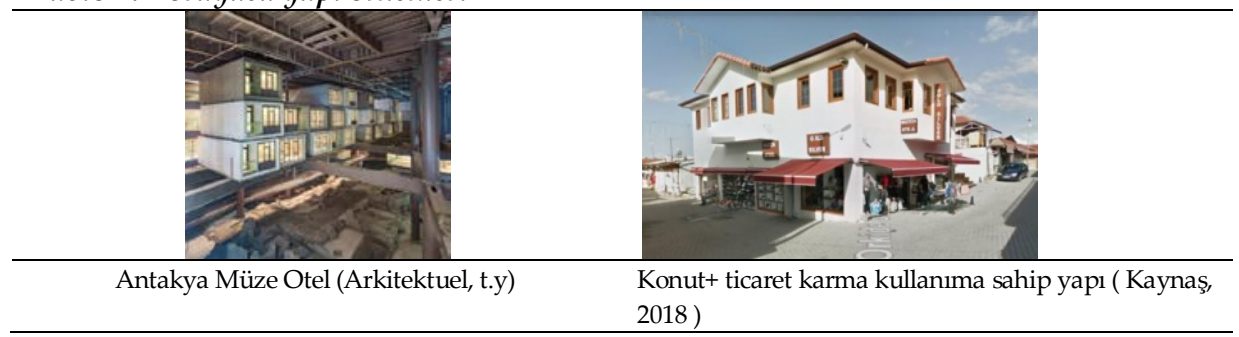

Örtü tasarımında öncelikli amaç arkeolojik alanın korunması olmalıdır. Alan için tehlike oluşturabilecek çevresel ve iklimsel faktörlerin tamamına karşı korunması sağlanmalıdır (İpekoğlu ve Çetin, 2013). Kalıntılar nem, rüzgar, gün 1şığı, malzeme, ziyaretçi gibi çeşitli parametrelerden zarar görebilir. Nem nedeniyle tuz ve buharın kalıntı üzerinde birikimi strüktürel dayanımında azalmalara, malzeme bozulmalarına sebep olur (Graeve, 2005). Rüzgar, malzeme üzerine yük uygulamakta ve bu yük strüktürün konumuna ve formuna göre değişiklik göstermektedir (Bachmann, 2006). Aynı zamanda aşındırıcı etkisiyle kalıntı üzerinde biyolojik aktiviteye neden olabilecek toz gibi maddelerin birikmesine neden olur (Dikilitaş, 2011). Güneş ışınları ise barındırdıkları alfa parçacıkları nedeniyle renklerin solmasına, malzeme içyapılarının değişmesine neden olur. Güneş ışığını içeriye alan, hava sirkülasyonunu sınırlayıp isı artışına neden olan malzemeler tercih edilmemelidir. Yapılacak olan tasarımla ziyaretçi yönetimi de sağlanmalıdır. Alanın ziyaretçi için tehlike oluşturan unsurlarına çözüm üretilirken aynı zamanda ziyaretçinin de alana olumsuz etkilerinin önüne geçilmelidir (Zeren ve Uygar, 2010). Arkeolojik alanlar için çevrede yaşayan hayvanlar da tehlike oluşturabilir. Bu nedenle koruyucu örtü altında kuş, kedi, köpek gibi hayvanların barınmasının önüne geçilmelidir (Dikilitaş, 2011). Örtü tasarımında oluşturulan strüktürün iddialı ve anıtsal görünüme sahip olmaması uygun görülür (Ahunbay, 1999). Ancak mirası ikinci planda bırakarak odak noktası haline gelen tasarımlar da bulunmaktadır. Bu tür çözümlerde tasarım ilgi uyandırsa da korunacak değerlerin vurgulanması daha uygundur (Hauselmayer, 2000). Koruyucu örtüler arkeolojik alana yapılan çağdaş eklerdir. Geçmişten günümüze koruma alanında çağdaş eki konu alan belgeler incelendiğinde kendi döneminin mimari ve kentsel yap1sını yansıtması gerektiği, mevcut değerleri koruyarak dönemsel malzemeler ve tekniklerle farklılaşmanın sağlanması gerektiği belirtilmektedir (ICO- 
MOS, 1987). Strüktür tasarımında ise deprem gibi yüklere karşı dayanıklı, uzun ömürlü malzemeler tercih edilmelidir. Koruyucu örtünün oluşturulmasıyla zemine yapılan yük aktarımı, zemine noktasal temas eden, kalıntılara zarar vermeyecek şekilde yapılmalı ve strüktür, alanın plan şemasına uygun nitelikte tasarlanmalıdır (Zeren ve Uygar, 2010).

Kullanılacak koruyucu örtü türü seçiminde iklim, arazi şartları, kalıntıların özellikleri ve durumu, bütçe gibi çeşitli parametreler rol almaktadır. Asıl amacı arkeolojik alanın korunması olan koruyucu örtülerin tasarımıyla alan için tehlike oluşturan durumların önüne geçilmelidir. Her bir örtünün arkeolojik alanla bütünleşirken izlediği tasarım yaklaşımı, seçtiği malzeme farklılık göstermektedir. Bu çalışmada ise kalıntılar üzerine inşa edilen müze yapılarının tasarımında nasıl bir yaklaşım izlendiğini mevcut yapılar üzerinden ortaya koyarak bir tipoloji oluşturmak ve benzer kurguda inşa edilecek olan yapıların tasarımlarına 1şık tutmak amaçlanmaktadır. Araştırma probleminin müze yapılarına uygunluğunun nedeni; diğer işlevlere sahip koruyucu yapılara göre daha çok örneğin bulunması, izlenilen tasarım yaklaşımı ve kullanılan malzeme çeşitliliğidir.

Çalışmada, arkeolojik alanda koruyucu yapı ve tasarım, arkeolojik alanda üst örtü ve tasarım, arkeolojik alan üstüne yapılan yapılar anahtar kelimeleriyle Google Scholar, YÖK Tez veri tabanlarından tarama yapılarak literatür incelenmiş ve ulaşılan çalışmalar içerikleriyle beraber açıklanmıştır (Tablo 3).

\section{Tablo 3. Literatür Taraması}

\begin{tabular}{llll}
\hline Adı & Yıl & Yazar & Tür \\
\hline $\begin{array}{l}\text { Arkeolojik Alanlarda Koruma Çatıları Ve Gezi Platform- } \\
\text { larmın Düzenlenmesi Kriterleri }\end{array}$ & 2010 & $\begin{array}{l}\text { Mine Tanaç Zeren, } \\
\text { Oğuzhan Uyar }\end{array}$ & Makale \\
\hline $\begin{array}{l}\text { Arkeolojik Alanlarda Uygulanan Koruma Örtülerinin } \\
\text { Tasarım Kriterleri }\end{array}$ & 2019 & $\begin{array}{l}\text { Mesut Yılmaz } \\
\text { Yaşar Selçuk Şener } \\
\text { Arzu Bakıroğlu Yılmaz }\end{array}$ & Makale \\
\hline Arkeolojik Alanlarda Üst Örtü Tasarım Kriterleri & 2020 & $\begin{array}{l}\text { Murat Oral } \\
\text { Elife Büyüköztürk }\end{array}$ & Makale \\
\hline $\begin{array}{l}\text { Protective Structures fort he Conservation and Presenta- } \\
\text { tion of Archaeological Sites }\end{array}$ & 1997 & Zaki Aslan & Makale \\
\hline $\begin{array}{l}\text { III. Derece Arkeolojik Sitlerde Yer Alan Yeni Yapılarda } \\
\text { Mekânsal Biçimleniş Analizi }\end{array}$ & 2018 & $\begin{array}{l}\text { Havva Burcu } \\
\text { Kaynaş }\end{array}$ & Yüksek Lisans Tezi \\
\hline $\begin{array}{l}\text { Tescilli Arkeolojik Buluntu Alanlarında, Yeni Yapılanma } \\
\begin{array}{l}\text { Ve Koruma Yaklaşımlarının Tespiti ve İrdelenmesi: Sinop } \\
\text { Örneği }\end{array}\end{array}$ & Mahitap Sel & Yüksek Lisans Tezi \\
\hline $\begin{array}{l}\text { Evaluatıon of Protectıve Structures } \\
\text { In Archaeological Sites for In Situ Conservatıon of Archı- } \\
\text { tectural Remains and Artıfacts }\end{array}$ & 2012 & Atiye Işıl Ertosun & Yüksek Lisans Tezi \\
\hline
\end{tabular}




\begin{tabular}{llll}
\hline $\begin{array}{l}\text { Architectural Desıgn Characterıstıcs } \\
\text { of Protectıve Structures at }\end{array}$ & 2013 & $\begin{array}{l}\text { Necmiye Funda } \\
\text { Yaka Çetin }\end{array}$ & Doktora Tezi \\
$\begin{array}{l}\text { Archaeological Sites and Their Impact } \\
\text { on Conservatıon of Remains }\end{array}$ & & \\
\hline
\end{tabular}

Zeren ve Uyar, Arkeolojik Alanlarda Koruma Çatıları Ve Gezi Platformlarının Düzenlenmesi Kriterleri (2010) adlı çalışmalarında arkeolojik alanlarda bulunan koruma çatıları ve gezi platformlarının planlama süreçlerini, tasarımlarında dikkat edilmesi gereken noktaları örnekler üzerinden açıklamışlardır. Yılmaz, Şener ve Bakıroğlu Yılmaz, Arkeolojik Alanlarda Uygulanan Koruma Örtülerinin Tasarım Kriterleri (2019) adlı çalışmalarında mevcut koruyucu örtüler üzerinden örnekler verip tasarımda göz önüne alınması gereken noktalara değinmiştir. Bunun yanında Oral ve Büyüköztürk, Arkeolojik Alanlarda Üst Örtü Tasarım Kriterleri (2020) adlı çalışmasinda Çatalhöyük, Arslantepe gibi Türkiye'de bulunan birkaç arkeolojik alana ait üst örtüleri inceleyerek tasarım kriterlerini ortaya koymuştur. Yaka Çetin, 2013 yılında yayınlamış olduğu doktora tezinde on altı adet koruyucu yapının mimari özelliklerini inceleyerek arkeolojik alandaki etkilerini tespit etmiştir. Kaynaş, III. Derece Arkeolojik Sitlerde Yer Alan Yeni Yapılarda Mekânsal Biçimleniş Analizi (2018) yüksek lisans tezinde Antalya ve Konya illerinde temelinde arkeolojik kalıntı bulunan yapıları tasarım, inşa ve kullanım süreçleri inceleyerek analiz etmiştir. Sel ise 2018 yılında yayınladığ1 yüksek lisans tezinde Sinop'ta arkeolojik kalıntı çıkan parsellerdeki yeni yapılaşmalarda izlenen koruma yaklaşımını incelemiştir. Ertosun, 2012 yılında yayınladığı yüksek lisans tezinde; Aslan ise 1997 tarihli makalesinde uygulanmış örnekleri değerlendirerek bu örneklerin kalıntılar üzerinde oluşturdukları etkilerden bahsetmektedir. Ayrıca Aslan, koruma amacıyla planlanacak gelecekteki projeler için bir kılavuz oluşturma ihtiyacına dikkat çekmiştir. Literatürde arkeolojik alan koruyucu örtülerin tasarım kriterleri ya da mevcut örneklerin analiziyle ilgili çeşitli çalışmalar olsa da kalıntılar üzerine inşa edilen müze yapılarının tasarım yaklaşımları ve malzeme tercihleri incelenememiş olup çalışma kapsamında seçilen örnekler mevcut tez ve makalelerden farklıdır. Çalışma bu yönüyle literatüre katkı sağlamaktadir. 


\section{Yöntem}

Bu çalışma için birden fazla yöntem kullanılmıştır. Arkeolojik alanları koruyucu nitelikte olan müze yapılarının tespit edebilmek adına google arama motorunda yurt dışı örnekler için "site museum", "built on ruins" anahtar kelimelerini kullanırken Türkiye'deki örneklere erişebilmek için "kalıntılar üzerine inşa edilmiş müzeler", "arkeoloji ve müze" anahtar kelimeleri kullanılarak tarama yapılmış ve 24 adet yapıya ulaşılmıştır. Bu yapıların açık erişimli web sitelerinde taraması yapılarak mimari ve konsept projelerine erişilmiştir. Amaçlı örnekleme yöntemi türü olan ölçüt örnekleme yöntemiyle yapıların çözümlemesi yapılmıştır. Önceden oluşturulmuş ya da araştırmacı tarafından belirlenen ölçütleri karşılayan durumların çalışılması ölçüt örnekleme olarak tanımlanmaktadır ("Nitel Araştırmada Örneklem Seçimi", t.y.). 24 adet yapıdan müze yapısı inşa edilmemiş olan arkeoparklar, inşaat aşaması gerçekleşmemiş olan yarışma projeleri ve arkeolojik alanı koruyucu nitelikte olmasına karşın sonradan müze işlevi verilen tarihi yapılar da kapsam dışında tutulmuştur. Çalışma kapsamı arkeolojik alanı koruyucu nitelikte inşa edilen müze yapıları olarak sınırlandırılmıştır. 24 yapı içinden 10 yapı kapsam dışı kaldığı için çalışma örneklemi 14 adet yapıdan oluşmaktadır. Çalışmada öncelikle yapıları tanıtmak amacıyla künye bilgileri verilerek sergi malzemeleri değerlendirilmiştir. Tanıtılan yapılar içerik analizi yöntemiyle incelenerek tasarım yaklaşımları tespit edilmiş ve bir tipoloji denemesine gidilmiştir. İçerik analizi, verinin içeriğine ilişkin tekrarlanabilir ve geçerli sonuçlar çıkartmak üzere kullanılan araştırma tekniğidir (Krippendorff, 1980).

\section{Bulgular}

Yapıların daha kolay ifade edilebilmeleri için bulundukları ülkeler alfabetik sıraya göre sıralanmış ve her birine envanter numarası verilmiştir (Tablo 4). Oluşturulan tablolarda yapılar bu envanter numaraları ile belirtilmiştir.

Çalışma kapsamında incelenen 14 adet yapıdan Çekya, Çin, Hırvatistan, İsviçre, Japonya ve Yunanistan'da birer adet, Almanya, Fransa, İspanya ve Türkiye'de ise ikişer adet bulunmaktadır. 
Tablo 4. Envanter numaraları listesi

\begin{tabular}{lll}
\hline Envanter Numarası & Ülke/Şehir & Yapı Ad1 \\
\hline 1 & Almanya/Köln & Kolumba Müzesi \\
\hline 2 & Almanya/Xanten & LVR-Römer Museum \\
\hline 3 & Çekya & Archeopark Pavlov \\
\hline 4 & Çin/Chengdu & Jinsha Site Museum \\
\hline 5 & Fransa/Marsilya & Marseille History Museum \\
\hline 6 & Fransa/Périgueux & The Vesunna Gallo-Roman Museum \\
\hline 7 & Hirvatistan & Narona Archaeological Museum \\
\hline 8 & İspanya/Las Palmas & Cueva Pintada Museum and Archaeological Park \\
\hline 9 & İspanya/Palencia & Villa romana La Olmeda \\
\hline 10 & İviçre/Chur & Roman Ruins Shelter \\
\hline 11 & Japonya/Fukushıma & Miyahata Jömon Museum \\
\hline 12 & Türkiye/Aydın & Afrodisias Ek Müzesi \\
\hline 13 & Türkiye/Şanlıurfa & Şanlıurfa Haleplibahçe Mozaik Müzesi \\
\hline 14 & Yunanistan/Atina & Acropolis Museum \\
\hline
\end{tabular}

\section{Kalıntılar Üzerine İnşa Edilen Müzelerin Sergi Malzemelerinin Değerlendirilmesi}

Arkeoloji müzeleri, arkeolojik alanlardan çıkarılan çömlek, kap, testi gibi buluntuların sergilendiği müzelerdir. Sergilenen buluntular tek bir arkeolojik alandan getirilmiş olabileceği gibi birden fazla arkeolojik alandan da getirilmiş olabilir. Örneğin Şanlıurfa arkeoloji müzesinde Göbekli tepe, Nevalı Çori, Akarçay Tepe, Hessek Höyük, GreVirike, Lidar Höyük gibi farklı alanlardan çıkartılan buluntular sergilenmektedir (Şanlıurfa Arkeoloji Müzesi, t.y.). Bu tür müzeler genellikle arkeolojik alandan bağımsız konumda inşa edilmişlerdir. Buna karşın arkeolojik kalıntıların üzerine inşa edilen müzeler de bulunmaktadır.

Çalışma kapsamını oluşturan kalıntı üzerine inşa edilen müze yapıları incelendiğinde sergilenen buluntuların sadece üzerinde bulunduğu arkeolojik alana ait olduğu ya da üzerinde bulunduğu arkeolojik alan buluntularıyla birlikte başka arkeolojik alanlardan getirilen buluntuların da sergilendiği saptanmıştır. Bununla birlikte incelenen yapılar arasında sergilenen buluntunun hangi arkeolojik alana ait olduğuna dair bilgiye erişilemeyen müzeler de bulunmaktadır (Tablo 5). 
Tablo 5. Kalıntı üzerine inşa edilen müzelerin sergi malzemelerinin değerlendirilmesi

\begin{tabular}{|c|c|c|c|}
\hline & \multicolumn{3}{|c|}{$\begin{array}{l}\text { KALINTI ÜZERINE İNŞA EDİLEN MÜZELERIN SERGİ MALZEMELERINİN } \\
\text { DEĞERLENDİRILMESİ }\end{array}$} \\
\hline & $\begin{array}{l}\text { Sadece Alandaki } \\
\text { Buluntuların } \\
\text { Sergilendiği } \\
\text { Müzeler } \\
\end{array}$ & $\begin{array}{l}\text { Hem Alandaki Hem de } \\
\text { Başka Arkeolojik Alana } \\
\text { Ait Buluntuları Sergi- } \\
\text { lendiği Müzeler }\end{array}$ & $\begin{array}{l}\text { Buluntusu } \\
\text { Hakkında Bilgiye } \\
\text { Erişilemeyen Müzeler }\end{array}$ \\
\hline Yapı Envanter Numarası & 3,4 ve 12 & $1,2,5,13$ ve 14 & $6,7,8,9,10$ ve 11 \\
\hline \multirow[t]{2}{*}{ Toplam (Yüzde) } & $3(\% 21,4)$ & $5(\% 35,7)$ & $6(\% 42,8)$ \\
\hline & \multicolumn{3}{|c|}{14 (\%100) } \\
\hline
\end{tabular}

Sadece alandaki buluntuların sergilendiği müzeler; arkeolojik kalıntı üzerine inşa edilmiş ve sadece o arkeolojik alandan çıkarılan çömlek, kap, testi gibi buluntuların sergilendiği müzelerdir. Incelenen 14 adet yapıdan \%21,4'lük oran ile 3 tanesinde sadece alandaki buluntular sergilenmektedir. $\mathrm{Bu}$ gruba giren yapıların envanter numaraları 3, 4 ve 12 olup yapı künye bilgileri Tablo 6'da belirtilmiştir.

Tablo 6. Sadece alandaki buluntularn sergilendiği müzelerin künye bilgileri

\begin{tabular}{|c|c|c|c|c|}
\hline $\begin{array}{l}\text { Envanter } \\
\text { Numaras1 }\end{array}$ & Yapı Adı & Yapı Fotoğrafı & Yapım Yılı & Mimarı \\
\hline 3 & $\begin{array}{l}\text { Archeopark } \\
\text { Pavlov }\end{array}$ & Arcdaily, t.y. ) & 2016 & $\begin{array}{l}\text { Architektonicka } \\
\text { Kancelar } \\
\text { Radko Kvet }\end{array}$ \\
\hline 4 & $\begin{array}{l}\text { Jinsha Site } \\
\text { Museum }\end{array}$ & Windhorsetour & 2007 & - \\
\hline 12 & $\begin{array}{l}\text { Afrodisias Ek } \\
\text { Müzesi }\end{array}$ & İzmimod, t.y) & 2007 & Cengiz Bektaş \\
\hline
\end{tabular}

Hem alandaki hem de başka arkeolojik alana ait buluntuların sergilendiği müzeler; arkeolojik kalıntı üzerine inşa edilmiş farklı arkeolojik alanlardan çıkarılan çömlek, kap, testi gibi buluntuların sergilendiği müzelerdir. İncelenen 14 adet yapidan \%35,7'lik oran ile 5 tanesi bu gruba dahi olmaktadır. $\mathrm{Bu}$ gruba giren yapıların envanter numaraları 1, 2, 5, 13 ve 14 olup künye bilgileri Tablo 7'de verilmiştir. 
Tablo 7. Hem alandaki hem de başka arkeolojik alana ait buluntularnn sergilendiği müzelerin künye bilgileri

\begin{tabular}{|c|c|c|c|c|}
\hline $\begin{array}{l}\text { Envanter } \\
\text { Numarası }\end{array}$ & Yapı Adı & Yapı Fotoğrafi & $\begin{array}{l}\text { Yapim } \\
\text { Yili }\end{array}$ & Mimarı \\
\hline 1 & $\begin{array}{l}\text { Kolumba } \\
\text { Museum }\end{array}$ & (Inexhibit, t.y) & 2007 & $\begin{array}{l}\text { Peter } \\
\text { Zumthor }\end{array}$ \\
\hline 2 & $\begin{array}{l}\text { LVR-Römer } \\
\text { Museum }\end{array}$ & (Kuladig, t.y) & 2008 & $\begin{array}{l}\text { Dörte } \\
\text { Gatermann ve } \\
\text { Elmar Schos- } \\
\text { sig }\end{array}$ \\
\hline 5 & $\begin{array}{l}\text { Marseille } \\
\text { History } \\
\text { Museum }\end{array}$ & $\begin{array}{c}\text { (Divisare, t.y) } \\
\text { (Dive }\end{array}$ & 2013 & Roland Carta \\
\hline 13 & $\begin{array}{l}\text { Şanlıurfa } \\
\text { Haleplibahçe } \\
\text { Mozaik Müzesi }\end{array}$ & (Wikipedia, t.y) & 2015 & - \\
\hline 14 & $\begin{array}{l}\text { Acropolis } \\
\text { Museum }\end{array}$ & (Archdaily, t.y) & 2009 & $\begin{array}{l}\text { Bernard } \\
\text { Tschumi } \\
\text { Architects }\end{array}$ \\
\hline
\end{tabular}

Buluntusu hakkında bilgiye erişilemeyen müzeler; çalışma kapsamında incelenen 14 adet yapıdan $\% 42,8^{\prime}$ lik oran ile 6 tanesinde sergilenen buluntuların hangi arkeolojik alana ait olduğu hakkında bilgiye erişilememiştir. Bu yapıların envanter numaraları 6, 7, 8, 9, 10 ve 11 olup künye bilgileri Tablo 8 'de verilmiştir. 
Tablo 8. Buluntusu hakkında bilgiye erişilemeyen müzeler

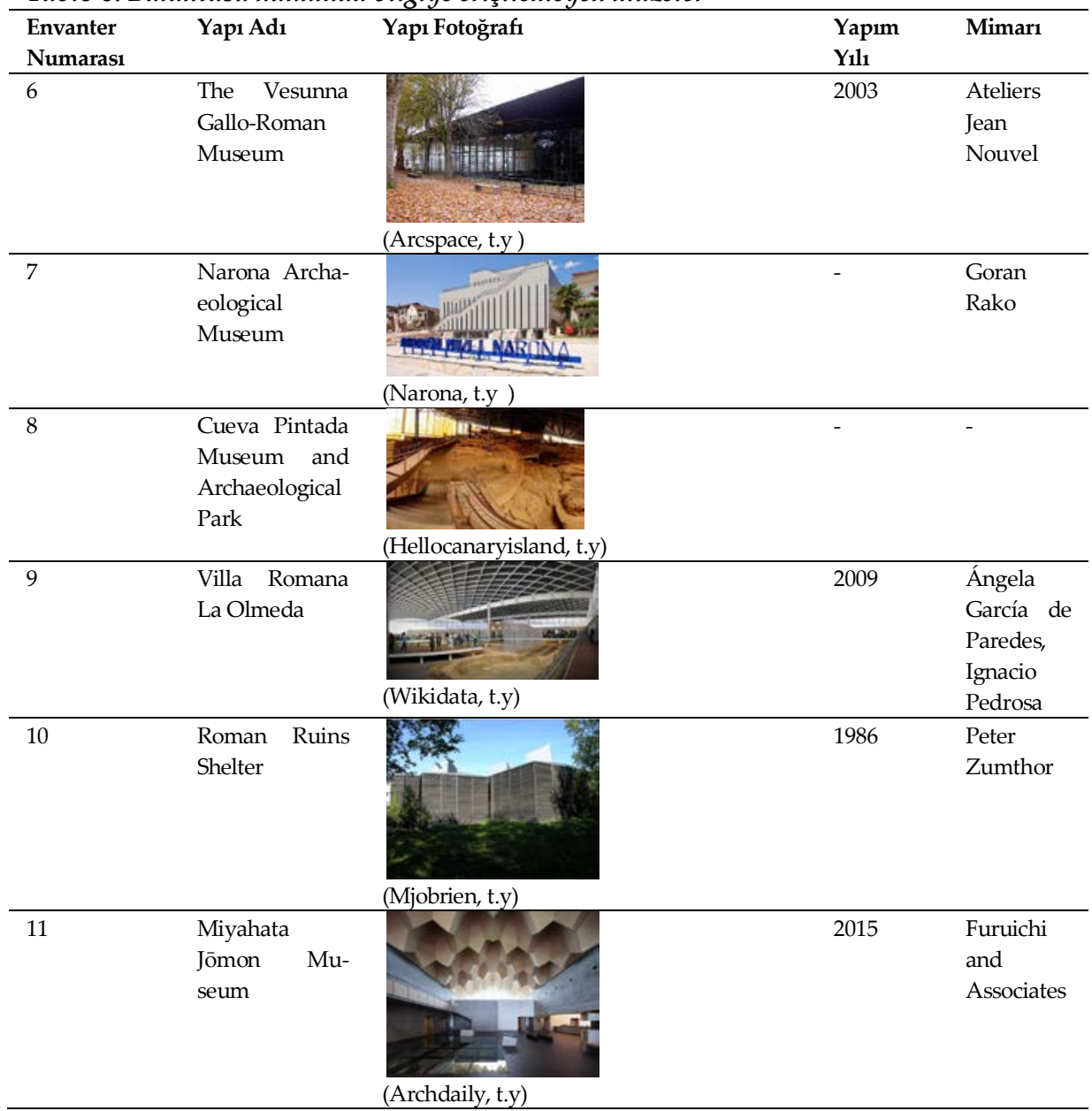

Kalıntılar Üzerine İnşa Edilen Müzelerin Tasarmm Yaklaşımlarının Değerlendirilmesi

Tablo 9. Yapının zeminle olan ilişkisi

\begin{tabular}{llll}
\hline & & $\begin{array}{l}\text { Zemine } \\
\text { Oturan } \\
\text { Yapılar }\end{array}$ & $\begin{array}{l}\text { Zeminden } \\
\text { Yükseltilmiş } \\
\text { Yapılar }\end{array}$ \\
\hline $\begin{array}{l}\text { Yapı Envanter } \\
\text { Numaraları }\end{array}$ & $1,3,4,5,6,7,8,9,10,11,13$ & 2,12 ve 14 & \\
\hline $\begin{array}{l}\text { Toplam } \\
\text { (Yüzde) }\end{array}$ & $11(\% 78,5)$ & $3(\% 21,5)$ & \\
\cline { 2 - 4 }
\end{tabular}


Çalışma kapsamında incelenen arkeolojik kalıntıların üzerine inşa edilen müzelerin tasarım yaklaşımlarını tespit edebilmek adına bir tipoloji denemesine gidilmiştir. Öncelikle yapıların zemin kotuyla ilişkisi incelenmiş ve iki farklı yaklaşım olduğu saptanmıştır. Yapının zemin kotuyla olan ilişkisi, " zeminden yükseltilmiş yapılar" ve "zemine oturan yapılar" olmak üzere iki ana kategoriye ayrılmaktadır (Tablo 9). Çalışmanın akış şemasına göre kategoriye ayrılan yapılar çatı, cephe ve strüktürel sistemleri başlıkları altında incelenmiştir (Şekil 1).

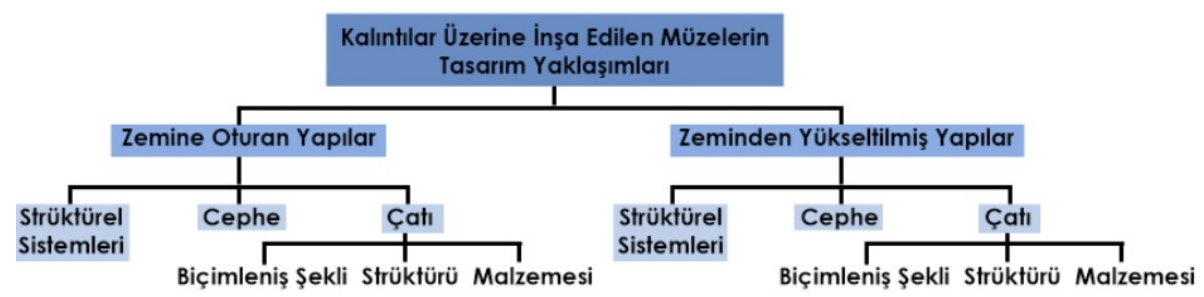

Şekil 1. Çalışma akış şeması

\section{Zemine Oturan Yapılar}

Bu tip uygulamalarda yapı giriş kotuyla zemin kotu aynı seviyededir. İncelenen 14 adet yapıdan $\% 78,5^{\prime}$ lik oran ile 11 tanesinde yapı zemine oturmaktadır. Bu yapıların envanter numaraları; 1, 3, 4, 5, 6, 7, 8, 9, 10, 11 ve 13'dür (Tablo 9). Bu gruba dahil olan yapıların tasarım yaklaşımları strüktür, cephe ve çatı başlıkları altında incelenmiştir.

\section{Strüktürel Sistem}

Çalışma kapsamında incelenen, kalıntıların üzerine inşa edilmiş ve zemine oturan 11 adet yapının strüktürel sistemleri incelenmiştir. 11 adet yapıdan $\% 45,4^{\prime}$ lük oran ile 5 adedinde betonarme strüktür, $\% 36,3^{\prime} l u ̈ k$ oran ile 4 adedinde çelik strüktür kullanıldığ1 saptanmıştır. \%18,1'lik oranla da 2 adet yapıda betonarme ve çelik strüktür bir arada kullanıldığı gözlemlenmiştir. Envanter numarası 1, 3, 5, 11 ve 13 olan yapılarda betonarme strüktür, 4, 8, 9 ve 10 envanter numaralı yapılarda çelik strüktür kullanılırken 6 ve 7 envanter numaralı yapılarda betonarme ve çelik strüktür birlikte kullanılmıştır (Tablo 10). 
Tablo 10. Kalıntılar üzerine inşa edilmiş ve zemine oturan yapıların strüktürel sistemleri

\begin{tabular}{llll}
\hline \multicolumn{4}{c}{ STRÜKTÜREL SISTEM } \\
\hline & Betonarme & Çelik & Betonarme ve Çelik \\
\hline Yapı Envanter Numarası & $1,3,5,11$ ve 13 & $4,8,9,10$ & 6 ve 7 \\
\hline Toplam (Yüzde) & $5(\% 45,4)$ & $4(\% 36,3)$ & $2(\% 18,1)$ \\
\cline { 2 - 4 } & \multicolumn{3}{c}{$11(\% 78,5)$} \\
\hline
\end{tabular}

\section{Cephe}

Kalıntıların üzerine inşa edilmiş ve zemine oturan 11 adet yapının cepheleri incelenmiş ve farklı malzemelerin kullanıldığ 1 tespit edilmiştir. 11 adet yapıdan \%9'luk oran ile 1 adet yapıda tuğla, \%18,1'lik oranla 2 adet yapıda ahşap, \%27,2'lik oranla 3 adet yapıda brüt beton, \%9'luk oran ile 1 adet yapıda plastik panel, $\% 9^{\prime}$ luk oran ile 1 adet yapıda metal perfore, $\% 9^{\prime}$ luk oran ile 1 adet yapıda taş kaplama, \%9'luk oran ile 1 adet yapıda membran, $\% 9^{\prime} l u k$ oran ile 1 adet yapıda sıvalı yüzey, \%27,2' lik oran ile de 3 adet yapıda cam cephe malzemesi olarak kullanılmıştır. Envanter numarası 1 olan yapıda tuğla, 10 numaralı yapıda ahşap, 3 numaralı yapıda brüt beton, 13 numaralı yapıda sıva, 7 numaralı yapıda plastik panel, 8 numaralı yapıda membran, 5 ve 6 numaralı yapılarda ise cam kullanılmıştır. 4, 9 ve 11 numaralı yapılarda birden fazla cephe malzemesinin kullanıldığı saptanmıştır. Envanter numarası 4 olan yapıda taş kaplama ve cam bir arada kullanılırken 9 numaralı yapıda brüt beton ve metal perfore bir arada kullanılmıştır. 11 numaralı yapıda ise ahşap ve brüt beton bir arada kullanılmıştır (Tablo $11)$.

Tablo 11. Kalıntılar üzerine inşa edilmiş ve zemine oturan yapılarn cephe malzemeleri

\begin{tabular}{|c|c|c|c|c|c|c|c|c|c|}
\hline \multicolumn{10}{|c|}{ CEPHE MALZEMESI } \\
\hline & Tuğla & Ahşap & $\begin{array}{l}\text { Brüt } \\
\text { Beton }\end{array}$ & $\begin{array}{l}\text { Plastik } \\
\text { Panel }\end{array}$ & $\begin{array}{l}\text { Metal } \\
\text { Perfore }\end{array}$ & $\begin{array}{l}\text { Taş } \\
\text { Kaplama }\end{array}$ & Membran & Cam & $\begin{array}{l}\text { Sivalı } \\
\text { Yüzey }\end{array}$ \\
\hline $\begin{array}{l}\text { Yapı } \\
\text { envanter } \\
\text { numarası }\end{array}$ & 1 & 10,11 & $3,9,11$ & 7 & 9 & 4 & 8 & $4,5,6$ & 13 \\
\hline $\begin{array}{l}\text { Toplam } \\
\text { (Yüzde) }\end{array}$ & $\begin{array}{l}1 \\
(\% 9)\end{array}$ & $2(\% 18,1)$ & $\begin{array}{l}3 \\
(\% 27,2)\end{array}$ & $1(\% 9)$ & $\begin{array}{l}1 \\
(\% 9)\end{array}$ & $\begin{array}{l}1 \\
(\% 9)\end{array}$ & $\begin{array}{l}1 \\
(\% 9)\end{array}$ & $\begin{array}{l}3 \\
(\% 27,2)\end{array}$ & $\begin{array}{l}1 \\
(\% 9)\end{array}$ \\
\hline \multicolumn{10}{|c|}{$11(\% 78,5)$} \\
\hline
\end{tabular}

\section{Çatı}

Çalışma kapsamında çatılar biçimleniş şekilleri, strüktürleri ve kaplama malzemeleri olmak üzere üç kısımda incelenmiştir. İncelenen yapıların çatı- 
larının düz, parçalı düz, eğimli ya da parçalı eğimli oldukları gözlemlenmiştir. 11 adet yapıdan $\% 18,1^{\prime}$ lik oran ile 2 adet yapıda düz, $\% 27,2^{\prime}$ lik oran ile 3 adet yapıda parçalı düz, \%36,3'lük oran ile 4 adet yapıda eğimli, \%27,2'lik oran ile 3 adet yapıda parçalı eğimli çatı kullanılmıştır. Envanter numarası 6 olan yapıda düz, 1, 7 ve 10 olan yapıda parçalı düz, 4,8 ve 13 olan yapıda eğimli, 3, 5 ve 9 olan yapıda parçalı eğimli çatı kullanılmıştır. 11 numaralı yapıda ise düz ve eğimli çatı bir arada kullanılmıştır (Tablo 12).

Tablo 12. Kalıntılar üzerine inşa edilmiş ve zemine oturan yapıların çatı biçimleniş şekilleri ve çatı strüktürleri

\begin{tabular}{lllll}
\hline & \multicolumn{4}{c}{ ÇATI BİÇiMLENİ̧ ŞEKLİ } \\
\hline & Düz & Parçalı düz & Eğimli & Parçalı eğimli \\
\hline Yapı envanter numarası & 6 ve 11 & 1,7 ve 10 & $4,8,11$ ve 13 & 3,5 ve 9 \\
\hline Toplam (Yüzde) & $2(\% 18,1)$ & $3(\% 27,2)$ & $4(\% 36,3)$ & $3(\% 27,2)$ \\
\cline { 2 - 5 } & \multicolumn{5}{c}{$11(\% 78,5)$} \\
\hline
\end{tabular}

\begin{tabular}{llll}
\hline & \multicolumn{4}{c}{ ÇATI STRÜKTÜRÜ } \\
\hline & Ahşap & Çelik & Betonarme \\
\hline Yapı envanter numarası & 1,9 ve 11 & $4,6,8,9,10$ ve 13 & $1,3,5$ ve 7 \\
\hline Toplam (Yüzde) & $3(\% 27,2)$ & $6(\% 54,5)$ & $4(\% 36,3)$ \\
\cline { 2 - 4 } & \multicolumn{3}{c}{$11(\% 78,5)$} \\
\hline
\end{tabular}

Yapıların çatı strüktürlerinde ise ahşap, çelik ve betonarme kullanıldığı görülmüştür. 11 adet yapıdan $\%$ 27,2'lik oran ile 3 adet yapıda ahşap, $\% 54,5^{\prime}$ lik oran ile 6 adet yapıda çelik, \%36,3'lük oran ile 4 adet yapıda betonarme çatı strüktürü kullanılmıştır. Envanter numarası 1 ve 11 olan yapılarda ahşap, 4, 6, 8, 10 ve 13 olan yapılarda çelik, 1, 3, 5 ve 7 olan yapılarda ise betonarme kullanılmıştır. 9 numaralı yapının çatı strüktüründe ise ahşap ve çelik bir arada kullanılmıştır (Tablo 12).

Kalıntılar üstüne inşa edilmiş ve zemine oturan yapıların çatı malzemeleri incelendiğinde sandviç panel, taş, beton plak ve metal kullanıldığı tespit edilmiştir. 11 adet yapıdan \%36,3'lük oran ile 4 adet yapıda sandviç panel, $\% 18,1^{\prime}$ lik oran ile 2 adet yapıda taş, $\% 9^{\prime}$ luk oran ile 1 adet yapıda beton plak, $\% 18,1^{\prime}$ lik oran ile 2 adet yapıda metal çatı kaplama malzemesi olarak kullanılırken \%18,1'lik oran ile 2 adet yapıda çatı kaplama malzemesi detay bilgisine erişilememiştir. Envanter numarası 6, 8, 11 ve 13 olan yapılarda sandviç panel, 4 ve 7 numaralı yapılarda taş, 3 numaralı yapıda beton plak, 9 ve 10 numaralı yapılarda metal çatı kaplama malzemesi olarak kullanılırken 5 ve 
1 numaralı yapıların çatı kaplama malzeme detay bilgisine erişilememiştir (Tablo 13).

Tablo 13. Kalıntılar üzerine inşa edilmiş ve zemine oturan yapıların çatı kaplama malzemeleri

\begin{tabular}{|c|c|c|c|c|c|}
\hline & \multicolumn{5}{|c|}{ ÇATI MALZEMESİ } \\
\hline & Sandviç panel & Taş & Beton plak & Metal & $\begin{array}{l}\text { Detay bilgisi- } \\
\text { ne ulaşılama- } \\
\text { yan }\end{array}$ \\
\hline $\begin{array}{l}\text { Yap1 envanter } \\
\text { numarası }\end{array}$ & $6,8,11$ ve 13 & 4 ve 7 & 3 & 9 ve 10 & 5 ve 1 \\
\hline \multirow{2}{*}{$\begin{array}{l}\text { Toplam } \\
\text { (Yüzde) }\end{array}$} & $4(\% 36,3)$ & $2(\% 18,1)$ & $1(\% 9)$ & $2(\% 18,1)$ & $2(\% 18,1)$ \\
\hline & \multicolumn{5}{|c|}{$11(\% 78,5)$} \\
\hline
\end{tabular}

\section{Zeminden Yükseltilmiş Yapılar}

Bu tip uygulamalarda yapı zemin kat kotu zemin kotundan yüksek seviyededir. İncelenen 14 adet yapıdan \%21,5'lik oran ile 3 tanesinde yapı zeminden yükseltilmiştir. Bu yapıların envanter numaraları 2, 12 ve 14'dür (Tablo 9). Yine bu gruba dahil olan yapıların tasarım yaklaşımları strüktür, cephe ve çatı başlıkları altında değerlendirilmiştir.

\section{Strüktürel Sistem}

Çalışma kapsamında incelenen, kalıntıların üzerine inşa edilmiş ve zeminden yükseltilmiş 3 adet yapının strüktürel sistemleri incelenmiştir. 3 adet yapıdan \%33,3'lük oran ile 1 adedinde betonarme strüktür kullanılırken $\% 66,6^{\prime}$ lik oran ile 2 adedinde çelik strüktür kullanılmaktadır. Envanter numarası 14 olan yapıda betonarme strüktür kullanılırken, 2 ve 12 numaralı yapılarda çelik strüktür kullanılmaktadır (Tablo 14).

Tablo 14. Kalıntılar üzerine inşa edilmiş ve zeminden yükseltilmiş yapıların strüktürel sistemleri

\begin{tabular}{lcc}
\hline & \multicolumn{2}{c}{ STRÜKTÜREL SİSTEM } \\
\hline & Betonarme & Çelik \\
\hline Yapı envanter numarası & 14 & 2 ve 12 \\
\hline Toplam (Yüzde) & $1(\% 33,3)$ & $2(\% 66,6)$ \\
\cline { 2 - 3 } & \multicolumn{3}{c}{$3(\% 21,5)$} \\
\hline
\end{tabular}

\section{Cephe}

Kalıntıların üzerine inşa edilmiş ve zeminden yükseltilmiş 3 adet yapının cepheleri incelenmiş ve farklı malzemelerin kullanıldığı tespit edilmiştir. 3 
adet yapıdan $\% 33,3^{\prime}$ lük oran ile 1 adedinde klinker, $\% 66,6$ 'llk oran ile de 2 adedinde cam cephe malzemesi olarak kullanılmıştır. Envanter numarası 12 olan yapıda klinker kullanılırken, 2 ve 14 numaralı yapılarda cam kullanılmıştır (Tablo 15).

Tablo 15. Kalıntılar üzerine inşa edilmiş ve zeminden yükseltilmiş yapılarn cephe malzemeleri

\begin{tabular}{lcc}
\hline & \multicolumn{2}{c}{ CEPHE MALZEMESI } \\
\hline Kapı envanter numarası & Klinker & Cam \\
\hline Toplam (Yüzde) & 12 & 2 ve 14 \\
\hline & $1(\% 33,3)$ & $2(\% 66,6)$ \\
\cline { 2 - 4 } & & $3(\% 21,5)$ \\
\hline
\end{tabular}

\section{Çatı}

Çalışma kapsamında çatılar biçimleniş şekilleri, strüktürleri ve kaplama malzemeleri olmak üzere üç kısımda incelenmiştir. İncelenen yapıların çatılarının düz, parçalı düz, eğimli ya da parçalı eğimli oldukları gözlemlenmiştir. Kalıntı üzerine inşa edilen ve zeminden yükseltilmiş 3 adet yapıdan $\% 33,3^{\prime}$ lük oran ile 1 adedinde düz, $\% 33,3^{\prime}$ lük oran ile 1 adedinde parçalı düz, \%33,3'lük oran ile 1 adedinde parçalı eğimli oldukları gözlemlenmiştir. Envanter numarası 12 olan yapı düz, 14 numaralı yapı parçalı düz, 2 numaralı yapı ise parçalı eğimli çatıya sahiptir (Tablo 16).

Tablo 16. Kalıntılar üzerine inşa edilmiş ve zeminden yükseltilen yapılarn çatı biçimleniş şekilleri ve çatı strüktürleri

\begin{tabular}{lccc}
\hline & \multicolumn{3}{c}{ ÇATI BíçíMLENiş ŞEKLİ } \\
\hline Yapı envanter numarası & 12 & Parçalı düz & Parçalı eğimli \\
\hline Toplam (Yüzde) & $1(\% 33,3)$ & 14 & 2 \\
\cline { 2 - 4 } & \multicolumn{4}{c}{$1(\% 33,3)$} & $1(\% 33,3)$ \\
\hline
\end{tabular}

\begin{tabular}{lcc}
\hline & \multicolumn{2}{c}{ ÇATI STRÜKTÜR SISTEMI } \\
\hline & Betonarme & Çelik \\
\hline Yap1 envanter numarası & 14 & 2 ve 12 \\
\hline Toplam (Yüzde) & $1(\% 33,3)$ & $2(\% 66,6)$ \\
\cline { 2 - 4 } & & $3(\% 21,5)$ \\
\hline
\end{tabular}

Yapıların çatı strüktürlerinde ise betonarme ve çelik kullanıldığı görülmüştür. Kalıntılar üzerine inşa edilmiş ve zeminden yükseltilmiş 3 adet yapıdan $\% 33,3^{\prime}$ lük oran ile 1 adedinde betonarme strüktür, $\% 66,6^{\prime} l 1 k$ oran 
ile de 2 adedinde çelik strüktür kullanılmıştır. Envanter numarası 14 olan yapı betonarme strüktüre sahipken 2 ve 12 envanter numaralı yapılar çelik strüktüre sahiptir (Tablo 16).

Kalıntılar üzerine inşa edilen ve zeminden yükseltilmiş yapıların çatı malzemeleri incelendiğinde sandviç panel, çinko, beton plak ve cam kullanıldığı tespit edilmiştir. 3 adet yapıdan \%33,3'lük oran ile 1 adedinde sandviç panel, \%33,3'lük oran ile 1 adedinde çinko, \%33,3'lük oran ile 1 adedinde beton plak ve cam bir arada kullanılmıştır. Envanter numarası 2 olan yapıda sandviç panel kullanılırken 12 numaralı yapıda çinko, 14 numaralı yapıda beton plak ve cam bir arada kullanılmıştır (Tablo 17).

Tablo 17. Kalıntılar üzerine inşa edilmiş ve zeminden yükseltilen yapıların çatı malzemeleri

\begin{tabular}{lccc}
\hline & & ÇATI MALZEMESI & \\
\hline Yapı envanter numarası & Sandviç panel & Çinko & Beton plak ve cam \\
\hline Toplam (Yüzde) & 2 & 12 & 14 \\
& $1(\% 33,3)$ & $1(\% 33,3)$ & $1(\% 33,3)$ \\
\cline { 2 - 4 } & & $3(\% 21,5)$ & \\
\hline
\end{tabular}

\section{Tartışma ve Sonuç}

Arkeolojik alanlar, geçmişte yaşamış insanların yaşam tarzlarını, inançlarını, ritüellerini anlatan mekanlardır. İnsanların geçmişini bilme isteği; geçmişe ayna tutan bu alanları inceleme, tanıma ve koruma isteği uyandırmaktadır. $\mathrm{Bu}$ istek ulusal ve uluslararası yasalarda da yerini bulmakla birlikte koruma, evrensel bir nitelik kazanmıştır. Korunarak geleceğe aktarılması, tanıtılması, hedeflenen arkeolojik alanlardan çıkan kalıntı ve ya buluntuların sergilenmesi için en doğru yöntem eğer özel bir koruma gerektirmiyorsa yerinde korunmasıdır. In-situ olarak adlandırılan bu koruma türü sayesinde eserlerin çevresiyle ve birbirleriyle olan ilişkisinin bir bütün olarak algılanmasını sağlamaktadır.

In-situ'nun sağlanması için çeşitli uygulamalar söz konusudur. Arkeolojik alanın üzeri plastik örtülerle örtülebildiği gibi koruyucu yapılar ya da strüktürlerle de örtülerek yerinde korunması sağlanmaktadır. Koruyucu strüktürler alanın korumasını ve sergilenmesini sağlarken koruyucu yapılar koruma ve sergileme yanında alana yeni işlevler de kazandırmaktadır. Literatürde yer alan koruyucu örtü tasarımı kriterleri, öncelikli amacın arkeolojik alanı korumak olması gerektiğini; alan önüne geçen tasarımlardan uzak 
durulmasının daha uygun olduğunu; seçilen malzemelerin çeşitli etmenlere dayanıklı, gerektiğinde kolayca yenilenebilir, güneş ışınlarını alanın iklimsel konforuna uygun şekilde içeri alacak nitelikte olması gerektiğini; nem dengesinin sağlanarak hem alanın hem de strüktürün zarar görmesinin önüne geçilmesi gerektiğini; rüzgarın aşındırıcı etkisinin ve kalıntılar üzerinde toz gibi maddelerin birikmesinin önüne geçilmesi gerektiğini; örtünün alana uyumlu plan şemasıyla oluşturulmasını ve zemine temasının minimum sayıda, noktasal temas eden taşıyıcılarla sağlanması gerektiğini; oluşturulan tasarımla iklimsel konfor şartlarının sağlanmasının yanında insanların ve hayvanların oluşturdukları tehlikelerin de önüne geçilmesi gerektiğini belirtmektedir.

Çalışmanın amacı arkeolojik kalıntılar üzerine inşa edilen müze yapılarında uygulanan tasarım yaklaşımlarını değerlendirerek tipoloji oluşturmak ve yeni yapılacak yapılara ş̧ık tutmaktır. İncelenecek yapıların tespiti ve değerlendirilmesi için birden fazla yöntem kullanılmıştır. Öncelikle belirlenen anahtar kelimelerle tarama yapılmış ve 24 adet yapıya ulaşılmıştır. Çalışma kapsamını oluşturan arkeolojik alanı koruyucu nitelikte inşa edilen müze yapıları dışında kalan yapılar elenerek sadece 14 yapı örneklem grubunu oluşturmaktadır. İlk olarak yapılar sergi malzemelerine göre değerlendirilmiştir fakat $\% 42,8^{\prime}$ lik oran ile 6 adet yapının sergi malzeme bilgisine erişilememiştir. Hem alandaki hem de başka arkeolojik alana ait buluntuların sergilendiği müzeler 5 adet olmakla birlikte \%35,7 ile sadece alandaki buluntuların sergilendiği müzelerden ( 3 adet $\% 21,4)$ daha fazladır.

Tasarım yaklaşımları incelendiğinde yapıların ya zemine oturduğu ya da zeminden yükseltildiği gözlemlenmiştir. İncelenen 14 yapıda 11 adet $\% 78,5^{\prime}$ lik oran ile zemine oturan yapıların daha fazla olduğu tespit edilmiştir. Zeminden yükseltilen yapı arkeolojik alana noktasal temas etmekte ve daha az zarar görmesini sağlamaktadır. Buna karşın alan, çevresel ve iklimsel tehditlere açık hale gelmiş olur. Rüzgarın kalıntılara direkt teması yüzey aşınmalarına ve toz birikmesine neden olabilir. Ayrıca oluşturduğu hava akımıyla ısı dengesinin değişmesine ve malzeme bozulmalarına yol açabilir. Yağmur, kar yağışı gibi zemin suyunun değişimine neden olan iklim olaylan1 da alan için tehlike oluşturabilir. Kuş vb. hayvanlarında alana girme ihtimali bir diğer tehdit unsurudur. Bu tür yapılarda belirtilen tehlikelere karşı önlemler alınması gerekmektedir. Zemine oturan yapılar ise iklimsel bazlı sorunlardan daha uzak olmalarına karşın toprağa daha çok temas etmeleri 
yönüyle alanın daha çok zarar görmesine neden olabilmektedir. Yapıyla zeminin birleşme noktalarındaki drenaj problemleri çözülmeli, arkeolojik kalıntıların zarar görmesi engellenmelidir. Doğru havalandırma sistemleriyle iç mekandaki ısıl konfor ve nem dengesi sağlanmalıdır.

Zeminle olan ilişkilerine göre ayrıştırıldıktan sonra yapılar strüktürel sistemleri, cepheleri ve çatılarına göre incelenmiş kullanılan malzeme ve formları tespit edilmiştir. Zemine oturan yapıların strüktürlerinde $\% 45,4^{\prime} l u ̈ k$ oranla en fazla betonarme kullanılırken zeminden yükseltilmiş yapılarda ise $\% 66,6$ 'llk oranla en fazla çelik kullanıldığ hammaddelerinin kolay temin edilebilir olması, basınca dayanıklı olması, çeliğe göre ucuza mal edilmesi gibi çeşitli avantajları bulunmaktadır. Çeliğin ise betonarmeye göre daha geniş açıklık geçilebilmesi ve hafif olması tercih edilme nedenleri arasında sayılabilir. Alana minimum temas, geçilen açıklık, bütçe gibi çeşitli parametreler avantaj ve dezavantajlarıyla ele alınarak arkeolojik alana en az yükü bindirerek zarar görmesini engelleyecek strüktür seçilmelidir. Cephe malzemelerinde ise zemine oturan yapılarda $\% 27,2$ 'lik oranlarla en çok brüt beton ve cam kullanılırken zeminden yükseltilmiş yapılarda \%66,6'lık oranla en çok cam kullanıldığı saptanmıştır. Betonun cephe malzemesi olarak kullanımı, yapının dışarıyla ilişkisini keserek içe dönük hale gelmesine neden olur. Ayrıca güneş ışınlarının alana ulaşmasını engeller. Bu sayede malzeme içyapılarının bozulmasının ve renklerin solmasını önüne geçilebilir. En çok tercih edilen malzemelerden biri olan camda ise ışık geçirgenliğine ve dayanımına dikkat edilmeli, alan için tehlike oluşturabilecek unsurların önüne geçilmelidir. Yapıların çatı incelemeleri, biçimleniş şekli, strüktürü ve malzemesi olmak üzere üç kısımda incelenmiştir. Zemine oturan yapılarda \%36,3'lük oranla en fazla çatı biçimleniş şekli eğimli, \%54,5'lik oranla en çok kullanılan strüktür çelik ve \%36,3'lük oran ile en fazla kullanılan kaplama malzemesi sandviç panel iken zeminden yükseltilen yapılarda çatı biçimleniş şeklinin düz, parçalı düz ve parçalı eğimli arasında \%33,3'lük oranla eşit miktarda kullanıldığı, \%66,6'lık oranla en fazla çelik çatı strüktürünün kullanıldığı ve kaplama malzemesi olarak da sandviç panel, çinko, beton plak ile camın \%33,3'lük oranla eşit miktarda kullanıldığı tespit edilmiştir (Tablo 18). Çatı formları rüzgarın uyguladığı yükte değişime neden olmaktadır. Arkeolojik alanın bulunduğu yere ait gerekli analizler yapılmalı ve rüzgarın uyguladığı kuvvetin tehlike oluşturmayacak seviyede kalmasını sağlayan çatı formları tercih edilmelidir. 
Rüzgar yükünün yanında çatının oluşturulduğu strüktür de taşıyıcılar vasıtasıyla alana baskı uygulamaktadır. Baskıyı en az seviyede tutan, dayanıklı ve geçilen açıklığa uygun nitelikte çatı strüktürü seçilmelidir. Yine çatı kaplama malzemesi tercihi alana etki eden güneş ışığı, yağmur ya da kar suları gibi etmenlere göre yapılmalıdır.

Tablo 18. Çalışma kapsamında incelenen yapıların tasarım yaklaşımları

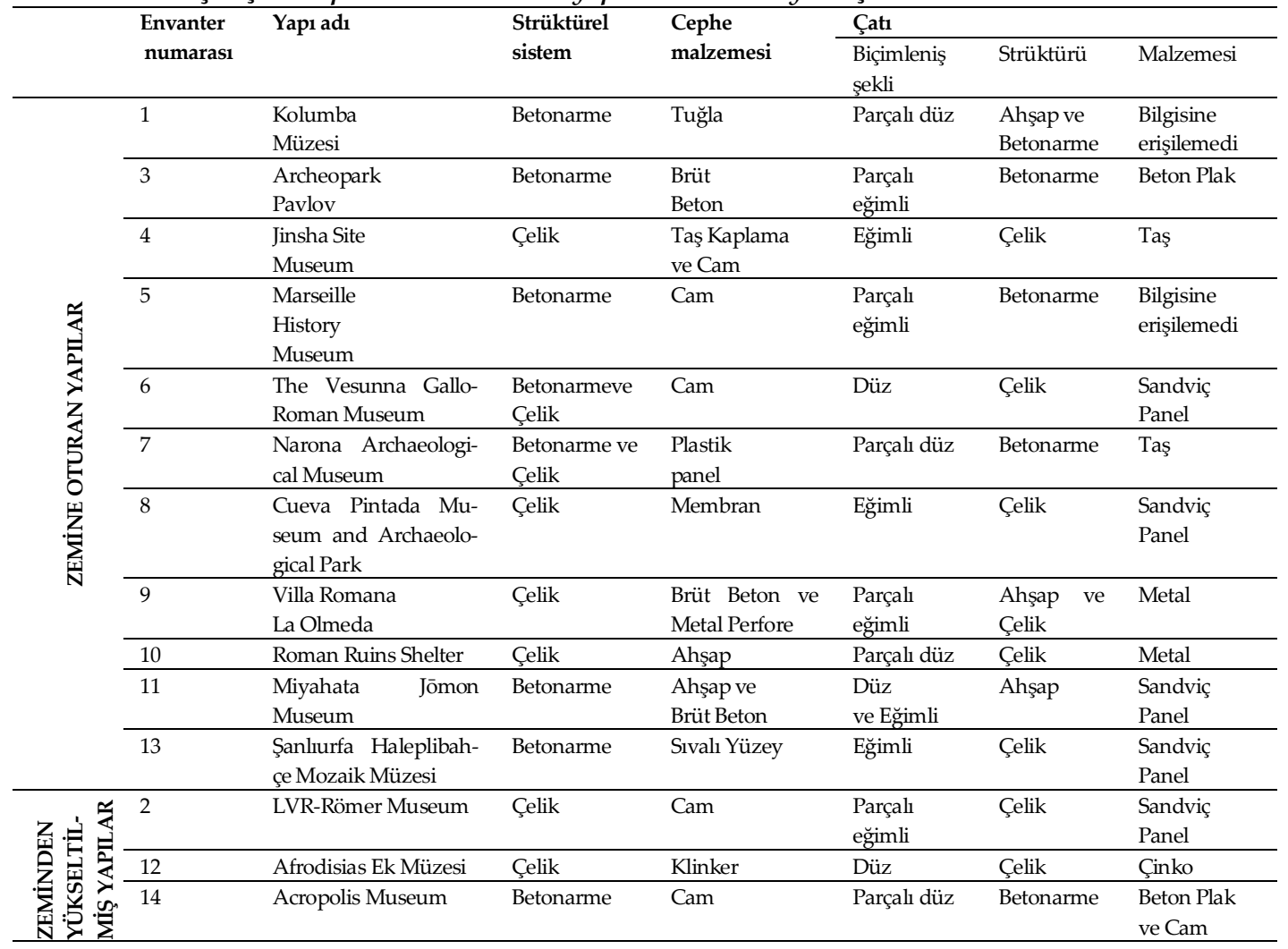

Strüktür, cephe ve çatı elemanlarıyla oluşan yapı, tasarımıyla arkeolojik alanın önüne geçmemeli sergilemeyi ön plana çıkartmalıdır. Buna karşın ilgi çekici tasarımlarla koruyucu örtüyle birlikte alanın da akılda kalıcılı̆̆ı arttırılabilmektedir. İncelenen örnekler içerisinde envanter numarası 10 olan Roman Ruins Shelter tasarımının yalınlığı ve kalıntıları ön plana çıkartması yönüyle olumlu bir örnek olarak verilebilir. Buna karşın envanter numarası 11 olan Miyahata Jōmon Museum'da yapının çatı tasarımı oldukça ilgi çeki- 
cidir. Bu nedenle arkeolojik alanla birlikte çatı tasarımı da odak noktası haline gelmektedir. Envanter numarası 4 olan Jinsha Site Museum, oluşturulan peyzajla bütünleşik olmasına karşın ölçek bazında anıtsal görünüme sahiptir. Envanter numarası 6 olan The Vesunna Gallo-Roman Museum ise çevre dokuyla daha uyumlu olup anitsalliktan uzaktır.

Yapılan çalışmada görüldüğü üzere, koruyucu yapıların tasarımında ve malzeme tercihlerinde çeşitlilik görülmektedir. Farklı yaklaşımlar izlenmiş olsa da ortak ve öncelikli amaç arkeolojik alanın korunarak varlığını devam ettirmesi, sergilenerek de hayatın bir parçası haline gelmesi olmalıdır. Alanın korunmasının sağlanabilmesi için arkeolojik alanın bulunduğu yerde gerekli analiz ve incelemeler yapılmall, iklimsel ve çevresel faktörler değerlendirilmeli, tehlike oluşturabilecek durumların önüne geçilmelidir. Her arkeolojik alan için alınması gereken önlem; konumu, barındırdığı kalıntıların özellikleri ve çevresel etmenlerinin farklı olması nedeniyle çeşitlilik göstermektedir. Bu nedenle geliştirilen tasarım önerileri ve malzeme seçimleri alana özgü olmall, sergileme amacını arka plana atmadan özgün mimari karakterini ortaya koymalıdır. Koruyucu örtünün tasarım bağlamı, rastgelelikten öte alanı korumalı ve kimliğini yansıtmalı, alanın değerini yükseltmeli, alanın hikâyesiyle ilişkili olmalıdır. 


\title{
EXTENDED ABSTRACT
}

\section{Design Approaches Of Museums Built On Archaeological Remains}

\author{
$*$ \\ Hicran Hanım Halaç - Cemre Su Abacı - Hilal Dağlı \\ Eskişehir Technical University
}

Archaeological sites transfer the construction techniques, lifestyles, beliefs, and cultures that existed in the past to the present. It is crucial for these areas. When these places, which have been protected under the ground for many years, are unearthed, they become open to destruction. Various solutions have been developed to preserve the residues against external factors. Some of these are protective roofs, shells, or structures that cover the ruins. With the use of protective covers, the archaeological site is protected in situ and can be perceived as a whole with its surroundings. How the covers should be designed is included in various national and international regulations. However, there are several studies in the literature on the design criteria of protective coverings. In these studies, it was mentioned that the designs to be made should take into account the environmental and climatic factors that pose a danger to the area and that no extra damage to the archaeological site should be done with the structure.

In the study, museums' design approaches on archaeological sites were examined through existing examples and aimed to create a typology. Moreover, it seeks to be a preliminary analysis for the new protective structures to be designed. For this purpose, various keywords were determined, and 24 frames were reached by scanning them on open-access websites. The architectural and concept projects of the buildings were examined by the criterion sampling method. Historical buildings that later became museums, competition projects that were not built and archeoparks that did not contain buildings were excluded. For this reason, ten buildings are excluded from the scope, and 14 buildings constitute the study sample. First of all, the exhibition materials were evaluated by giving information on the tag in order to introduce the buildings. The introduced structures were examined 
with the content analysis method, design approaches were determined, and a typology experiment was done.

When the museums' exhibition materials were evaluated, it was determined that only the finds in the area were exhibited or that the finds belonging to both the area and other archaeological sites were exhibited. However, there are museums among the structures examined, for which information about their finds is not available. In three of the 14 buildings $(21.4 \%)$, only the finds in the area are exhibited. In five buildings (35.7\%), findings from both the site and other archaeological sites are exhibited. There are six (42.8\%) buildings with no information about their finds.

In order to determine the design approaches, first of all, the relations of the buildings with the ground were examined, and a typology was created. In typology, the buildings are divided into two as sitting on the ground or raised from the ground. It has been determined that $11(78.5 \%)$ buildings sit on the ground, and $3(21.5 \%)$ buildings are raised from the ground. The structure raised from the ground touches the archaeological area point by point. In this way, it provides less damage to the area. However, the area becomes vulnerable to climatic threats. Factors such as wind and groundwater can pose a danger to the site, and various animals may enter the area. In such buildings, measures should be taken against climatic and environmental hazards. On the other hand, structures that sit on the ground can touch the soil more, causing more damage to the area. In these structures, drainage problems should be solved; the humidity and air balance in the interior should be ensured. The buildings classified in typology are examined according to their structural systems, facades, and roofs. The materials and forms used were determined. It was determined that reinforced concrete was used the most (45.4\%) in the structures of the buildings resting on the ground. Reinforced concrete has various advantages, such as being easily available and resistant to pressure. It was determined that the most (66.6\%) steel structure were used in the buildings raised from the ground. Among the advantages of steel is its ability to pass wide openings and its lightness. Various parameters such as minimum contact to the area, span, budget are effective in choosing the structure. The structure that will prevent damage by placing the least load on the area should be preferred. It has been determined that the most (27.2\%) exposed concrete and glass are used in the facade materials of the buildings resting on the ground. It was determined 
that glass was used mostly $(66.6 \%)$ in buildings raised from the ground. The use of exposed concrete in the facade prevents the sun rays from entering the area. In this way, material deterioration can be prevented. In the glass, attention should be paid to strength and light transmittance. The roofs of the buildings were examined in three parts: form, structure, and material. It has been determined that the shape of the roof in buildings resting on the ground is the most inclined (36.3\%), the most used structure $(54.5 \%)$ is steel, and the most used coating material (36.3\%) is sandwich panel. It has been determined that flat, segmented flat, and segmented slopes are used equally $(33.3 \%)$ in the roof formations in the structures raised from the ground, and steel is used the most $(66.6 \%)$ in the roof structure. In the coating material, it was determined that sandwich panel, zinc, concrete plate, and glass were used equally (33.3\%). The load applied by the wind varies according to the roof form. Roof forms that ensure that the applied load remains at a level that does not pose a danger to the area should be preferred. The roof structure that applies the least pressure to the area and suitable for the opening should be selected. Roof covering material should be selected that will not damage the area according to parameters such as sunlight and rain.

Among the structures examined, some examples highlight the remains with the simplicity of their design. On the other hand, there are designs that have become focal points with the archaeological site. There are structures with a monumental appearance, as well as structures that are more compatible with the surrounding tissue and far from monumentality.

As can be seen from the study, there is a variety in the protective structures' design and material preferences. Although there are different approaches, the primary goal should be to protect the archaeological site. In order to protect the area, necessary analysis and examinations should be made in the region where it is located. Climatic and environmental factors should be evaluated, and the elements that could pose a danger should be prevented. Measures to be taken for each archaeological site; It is diverse due to its location, characteristics of its ruins, and environmental factors. Therefore, material choices and design recommendations should be area specific. The design created should protect the archaeological site and help reflect its identity. 


\section{Kaynakça / References}

Açık Ders. (t.y.). Nitel araştırmada örneklem seçimi. https://acikders.ankara.edu.tr/pluginfile.php/85894/mod resource/content/0/ ders13 nitel $\% 20$ ara $\%$ C5\%9Ft $\%$ C4\%B1rmada $\% 20 \%$ C3\%B6rneklem $\% 20$ se $\%$ C3\%A7imi.pdf adresinden erişilmiştir.

Ahunbay, Z. (1999). Tarihi çeore koruma ve restorasyon. İstanbul: Yapı Endüstri Merkezi Yayınları.

Ahunbay, Z. (2010). Arkeolojik alanlarda koruma sorunları kuramsal ve yasal açlardan değerlendirme. Türkiye Bilimler Akademisi Kültür Envanteri Dergisi, 8, 103118. DOI: http://dx.doi.org/10.22520/tubaked.2010.0007

Archdaily. (t.y.). Archeopark Pavlov / Architektonicka kancelar Radko Kvet. 5 Ocak 2020 tarihinde https://www.archdaily.com/795684/archeopark-pavlov-kvetarchitects adresinden erişildi.

Archdaily. (t.y.). Miyahata Ruins Museum / Furuichi and Associates. 12 Temmuz 2020 tarihinde $\quad$ https://www.archdaily.com/787130/miyahata-ruins-museumfuruichi-and-associates adresinden erişildi.

Archdaily. (t.y.). New Acropolis Museum / Bernard Tschumi Architects. 6 Mayıs 2020 tarihinde $\quad$ https://www.archdaily.com/61898/new-acropolis-museumbernard-tschumi-architects/5009189028ba0d27a70017a3-new-acropolismuseum-bernard-tschumi-architects-image adresinden erişildi.

Arcspace. (t.y.). The Vesunna Gallo-Roman Museum. 5 Şubat 2020 tarihinde https://arcspace.com/feature/vesunna-gallo-roman-museum/ adresinden erişildi.

Arkitektuel. (t.y.). Antakya Müze Oteli. 8 Nisan 2020 tarihinde https://www.arkitektuel.com/antakya-muze-oteli/ adresinden erişildi.

Aslan, Z. (1997). Protective structures for the conservation and presentation of archaeological sites. Journal of Conservation and Museum Studies, 3, 16-20. DOI: http://doi.org/10.5334/jcms.3974

Bachmann, M. (2006). The Shelter over Bau Z in Pergamon. Z. Ahunbay, Ü. İzmirligil (Der.), Management and Preservation of Archaeological Sites içinde (s.40-44). İstanbul: Yapı Yayın.

Council of Europe. (1992). European convention on the conservation of archaeological heritage (Revised). Valetta.

Dikilitaş, G. (2011). Arkeolojik alanlarda koruma. Restorasyon Konservasyon Çalışmalarn Dergisi, 6, 43-51. https://dergipark.org.tr/tr/pub/restorasyon adresinden erişilmiştir. 
Divisare. (t.y.). Roland Carta Musée D'histoire De Marseille. 8 Şubat 2020 tarihinde https://divisare.com/projects/321646-studio-adeline-rispal-roland-carta-sergedemailly-musee-d-histoire-de-marseille adresinden erişildi.

$\begin{array}{llll}\text { Gezimanya. } & \text { (t.y.). Şanlıurfa Arkeoloji Müzesi. }\end{array}$ https://gezimanya.com/sanliurfa/gezilecek-yerler/sanliurfa-arkeoloji-muzesi Graeve, V. (2005). 2001-2003 millet çalışmaları. K. Olşen, H.Dönmez, A. Özme (Der.), 26. Kazı Sonuçları Toplantısı 1. Cilt içinde (s.207-222). Ankara: Kültür ve Turizm Bakanlığı DÖsiMM Basımevi.

Hauselmayer, O. (2000). Mimarlık ve proje gelişimi. E. Wien (Der.), Efes İçin Bir Çatı Yamaç Ev 2 Koruma Binası içinde (s. 101-114). Viyana: Österreichisches Archaologisches Institut.

Hellocanaryisland. (t.y.). Cueva Pintada. 4 Mayss 2020 tarihinde https://www.hellocanaryislands.com/museums-and-places-interest/grancanaria/cueva-pintada/ adresinden erişildi.

ICOMOS. (1964). The Venice charter, international charter for the conservation and restoration of monuments and sites. Venice.

ICOMOS. (1987). Charter for the conservation of historic towns and urban areas (Washington Charter 1987). Washington.

ICOMOS. (1990). Charter for the preservation and management of archaeological heritage. Swiss.

Inexhibit. (t.y.). Kolumba: Köln. 6 Şubat 2020 tarihinde https://www.inexhibit.com/mymuseum/kolumba-art-museum-colognepeter-zumthor/ adresinden erişildi.

İpekoğlu, B. ve Çetin, Y.F. (2013). Impact of transparency in the design of protective structures for conservation of archaeological remains. Journal of Cultural Heritage, 14 (3), 21-24. DOI: https://doi.org/10.1016/j.culher.2012.10.019

İzmimod. (t.y.). Afrodisyas Ek Müzesi. 5 Mayıs 2020 tarihinde http://www.izmimod.org.tr/egemim/65/36-41.pdf adresinden erişildi.

Kaderli, L. (2014). Kültürel miras koruma yaklaşımlarının tarihsel gelişimi. Türkiye Bilimler Akademisi Kültür Envanteri Dergisi, 12, 29-41. DOI: http://dx.doi.org/10.22520/tubaked.2014.0002

Kaynaş, H. B. (2018). III. derece arkeolojik sitlerde yer alan yeni yapılarda mekânsal biçimleniş analizi. Yüksek lisans tezi. https://tez.yok.gov.tr/UlusalTezMerkezi/ adresinden erişilmiştir.

Krippendorff, K. (1980). Content analysis: An introduction to its methodology. Beverly Hills: Sage Publications. 
Kuladig. (t.y.). Große Thermen im LVR-Archöologischen Park Xanten. 4 Mart 2020 tarihinde https://www.kuladig.de/Objektansicht/O-F]K-20100726-0006 adresinden erişildi.

Mjobrien. (t.y.). Roman Ruins Shelter. 7 Temmuz 2020 tarihinde https://mjobrien.com/ARCH606S09/zumthor roman ruins enclosure chur swi 1986.pdf adresinden erişildi.

Narona. (t.y.). Info O Muzeju. 7 Şubat 2020 tarihinde http://www.a-m-narona.hr/omuzeju/ adresinden erişildi.

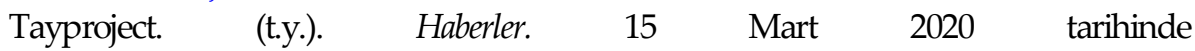
http://www.tayproject.org/haberarsiv20176.html adresinden erişildi.

Wikidata. (t.y.). Villa romana de La Olmeda. 5 Haziran 2020 tarihinde https://www.wikidata.org/wiki/Q4012812\#/media/File:La Olmeda 2009.jpg adresinden erişildi.

Wikipedia. (t.y.). Haleplibahçe Mozaik Müzesi. 5 Ocak 2020 tarihinde https://upload.wikimedia.org/wikipedia/commons/e/e9/Haleplibah\%C3\%A 7e Mozaik M\%C3\%BCzesi.jpg adresinden erişildi.

Windhorsetour. (t.y.). Explore Jinsha Site Museum. 3 Mayls 2020 tarihinde https://windhorsetour.com/blog/explore-jinsha-site-museum adresinden erişildi.

Yollardan. (t.y.). Malatya Arslantepe Höyüğü Ve tarihteki ilk Anadolu sarayı. 14 Mart 2020 tarihinde https://www.yollardan.com/arslantepe-hoyugu-bilgileri// adresinden erişildi.

Zeren, M. ve Uyar, O. (2010). Arkeolojik alanlarda koruma çatları ve gezi platformlarunn düzenlenmesi. Mühendislik Bilimleri Dergisi, 12(2), 55-64. https://dergipark.org.tr/tr/pub/deumffmd/issue/40833/492698 adresinden erişilmiştir.

\section{Kaynakça Bilgisi / Citation Information}

Halaç, H. H., Abacı, C. S. ve Dağlı, H. (2021). Arkeolojik kalıntılar üzerine inşa edilen müzelerin tasarım yaklaşımları. OPUSUluslararası Toplum Araştırmaları Dergisi, 17(35), 2225-2253. DOI: 10.26466/opus.822518 